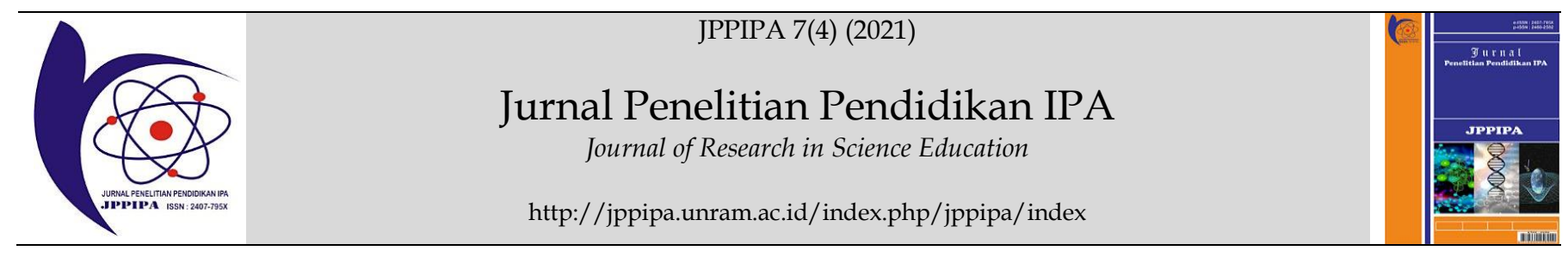

\title{
Implementation of STEM-Based Experiential Learning to Improve Critical Thinking Skills on Ecosystem Materials
}

\author{
Khairati $^{1}$, Wiwit Artika ${ }^{12}$, Muhammad Ali Sarong1 1 , Abdullah ${ }^{1}$, Hasanuddin $^{1}$ \\ ${ }^{1}$ Master of Biology Education Faculty of Teacher Training and Education, Syiah Kuala University, Banda Aceh, Indonesia \\ ${ }^{2}$ STEM Research Center, Syiah Kuala University, Banda Aceh, Indonesia
}

\section{DOI: $\underline{10.29303 / \text { ippipa.v7i4.850 }}$}

\section{Article Info}

Received : July 29th, 2021

Revised : September $6^{\text {th }}, 2021$

Accepted: October 17th, 2021

\begin{abstract}
The low critical thinking skills of learners are triggered by less supportive learning. The learning process has not emphasized the development of critical thinking skills, it is because in learning learners tend to memorize concepts so that critical thinking skills are not trained, making learners less active in the learning process and not achieving minimum completion criteria, there needs to be efforts to overcome them. The formulation of the problem in this study is: Is there a significant difference in the improvement of students' critical thinking skills with the implementation of STEM-based Experiential Learning learning in class VII MTsN Aceh Besar? This research aims to find out the significance of differences in improving learners' critical thinking skills with the implementation of STEM-based Experiential Learning learning. The method used in this study is an experimental method with the design of One Group Pretest-Postets design. The population of this study is all students of class VII MTsN Aceh Besar which amounted to 120 learners. The instrument used to measure critical thinking skills using multiple choice questions is 10 questions. Data analysis using the One Simple t-Test test at a significant level of 0.05 . The results of the One Simple t-Test test of the students' critical thinking skills were obtained by Sig. $(0.00)<(0.05)$, showed that learners' critical thinking skills were better and there was a significant improvement with the implementation of STEM-based Experiental Learning.
\end{abstract}

Keywords: Experiental Learning; STEM; Critical Thinking

Citation: Khairati, K., Artika, W., Sarong, M., Abdullah, A., \& Hasanuddin, H. (2021). Implementation of STEM-Based Experiential Learning to Improve Critical Thinking Skills on Ecosystem Materials. Jurnal Penelitian Pendidikan IPA, 7(4), $752-757$. doi:https://doi.org/10.29303/jppipa.v7i4.850

\section{Introduction}

Science learning is very fun learning that can be taught with various models, methods, and media that really interest learners in learning something in the environment. Teachers can create an active, innovative, effective, and fun learning atmosphere because learners are required to be able to improve their thinking skills better and critically. Based on the facts obtained during the learning process, critical thinking is considered an important educational goal that aims to develop students who are interested in sound thinking, reason, and good judgment in seeking clarity and authenticity (Khoiriyah, 2018).

Critical thinking is an intellectual process of conceptualizes, applying, analyzing, synthesizing, or evaluating information derived from observation, experience, reflection, where the results of this process are used as a basis when taking action (Syarif, 2010)

Critical thinking is the ability to reason and think reflectively directed to decide things that are convincing to do that are summarized in five groups, namely providing simple explanation (elementary clarification), building basic skills (basic support), 
concluding (interfence), making further explanations (advance clarification), as well as strategies and tactics or strategies or tactics (Ennis, 2011).

Critical thinking is a complex trait in learners who are certainly different from each other where learners are able to think and create spontaneously just by reviewing their experience based on the facts experienced, but for others, the teacher must be given a stimulus in order to be able to repeat the memory of acidification with three characteristics, namely (1) Spontane, (2) high curiosity, (3) interested in new things that can be studied (Khoiriyah, 2018).

There are several benefits of critical thinking: (1) Critical thinking is able to solve problems, (2) Critical thinking can help in decision making, (3) Critical thinking can distinguish between facts and opinions, (4) Critical thinking helps us to stay calm even in difficult problems (Khoiriyah, 2018).

Low critical thinking skills occur because learning is focused on the emphasis of concepts and not on the application of concepts. Learners only use mathematical calculations and do not apply their learning in engineering processes. This is evidenced by the inability of learners to respond to the answers to every question asked during learning. Students are less actively involved in learning and not much practice thinking, thus giving rise to the assumption that science does not feel its benefits in everyday life, especially facing challenges in the 21st century (Daud, 2013).

The measured critical thinking skills refer to the indicators of Ennis's critical thinking learning achievement in Mahfahroyin (2009), which is to provide simple explanations, build basic skills, conclude and provide further explanations. Indicators of Critical thinking skills consist of several Aspects. First, the Focus aspect, wherein this aspect learners are able to focus questions and provide simple explanations, taking a decision from the existing problems. Second, the aspect of reason, where learners are able to provide basic skills building by providing rational reasons for decisions taken. Third, the inference aspect, where learners are able to make conclusions based on convincing evidence by identifying. Fourth, the aspect of a situation where learners understand the key to the problem that causes a situation or situation and provide further explanations.

In the learning process, there needs to be improved so that learners are actively involved and gain hands-on experience to be able to improve problem-solving skills and thinking skills in IPA subjects. One learning model that can involve learners being active in learning and making the experience as a basis is an experiential learning model called Experiential Learning (Cahyo, 2013).

Experiential learning is a learning model that uses the experience as a medium of learning, reviewing experiences, inferring, and transforming experiences through actions by making observations and experiments (Cahyani, 2012). Experiential learning consists of four stages, namely concrete experience, reflective observation, abstract conceptualization, and active experiments with the implementation of learning that is expected to train the competence of learners so that the objectives of IPA subjects can be met and learners can train critical thinking (Yardley, 2012).

The purpose of Experiential Learning is to influence learners in three ways, namely (1) Changing the cognitive structure of learners, (2) changing the attitude of learners, (3) and expanding the skills of learners they experience, namely: (1) knowledge (concepts, facts, information), (2) activities (application in activities), (3) reflection that is the analysis of the impact of activities on individual development (Kusuma, 2014).

According to experiential learning theory, there are four steps of learners' abilities that can be observed in figure 1.

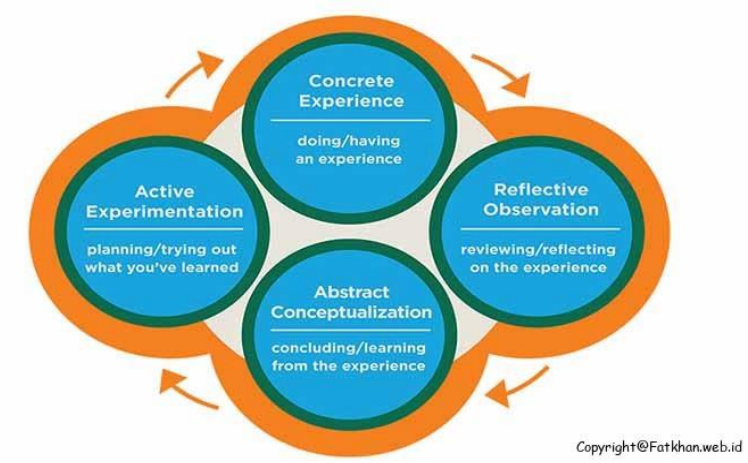

Figure 1. Exhibition Learning Model Step Scheme

Based on the scheme above, there are four abilities of learners according to experiential learning theory, namely (1) Concrete Experience (CE) that learners involve themselves fully in experience or Feeling, (2) Reflection Observation (RO) is learners observing and reflecting, thinking about experiences from various aspects or Watching (observing), (3) Abstract Conceptualization (AC) learners create concepts that integrate their observations into theory. Healthy or thinking (observing), (4) Active Experimentation (AE) learners use theory to solve problems and make decisions (Fathurrohman, 2015).

There are several advantages of Experiential Learning individually are (1) Raising awareness of selfconfidence, (2) Improving communication, planning, and problem-solving skills, (3) Cultivating and improving the ability to deal with bad situations, (4) 
Growing and increasing commitment and responsibility (5) Developing dexterity, physical abilities, and coordination (Fathurrohman, 2015).

During this learning process in class VII, MTsN

Aceh Besar is only done with a lecture learning model only and tends to learn individually. Learners are less able to cooperate in discussion groups and less sensitive to problems. The impact on critical thinking skills and learning outcomes of learners is still a low achievement of learners' values at the end of learning or not achieving KKM that has been set at 70 . While the average learner only obtained 45-60 with the number of 30 learners and the teacher stated that he did not know what the STEM approach in learning, so it can be said that teachers have never applied a STEM approach in learning.

Science learning, especially in ecosystem materials, can be taught using stem approaches, namely science in finding its concepts. In terms of technology can be taught by explaining various applications of technology related to materials. Through techniques, learners can be taught to make simple tools related to material, and mathematics is used to formulate mathematical equations related to material concepts. In terms of calculations, it is necessary to use a useful STEM approach to practice learners' critical thinking skills (Marjan, 2014).

STEM (Science, Technology, Engineering, and Mathematics) is an educational approach that integrates four disciplines, namely natural sciences (science), technology, engineering, and mathematics, by focusing the educational process on solving real problems and thinking critically in everyday life or professional life (Khoiriyah et al., 2018).

All four aspects in STEM take part in each implementation of learning steps. The steps of each of these aspects are as follows; (1) Aspect science is to discover the concept, (2) Aspect technology is the skill of learners in knowing how new technology can be developed, skills using technology and explaining various applications of technology related to the material, (3) Engineering aspects are taught to make simple tools related to material and draft a plan to achieve a goal such as the skill of stringing an experimental design, and (4) Aspects of Mathematics are skills used to analyze related material concepts, provide reasons, solve problems and interpret solutions based on data calculations (Aladé et al., 2016).

STEM aims to develop learners to (1) have the knowledge, attitudes, and skills to identify questions and problems in situations in their lives, explain natural phenomena, design, and draw conclusions, (2) Understand specific characteristics as a form of knowledge (Bybee, 2013).
Stem steps in experiential learning are (1) the teacher formulates what wants to be the final goal of the learning process, (2) The Teacher can start the material by introducing the discussion material by providing stimulation in the form of real events to provide an overview and direction of the student's thinking, (3) Learners in carrying out the learning process can be applied in groups or individuals, Most importantly they have some basic experiences that can be used to construct ideas, (4) Learners are taken to real circumstances or events, (5) Learners are given questions and answers with teachers related to the experience they have in learning the themes presented, (6) Learners make designs based on what has been learned to produce an ecosystem miniature (7) Teachers together with students provide conclusions and understandings that are true for learners.

The interrelationship of Experiental Learning with STEM approaches and critical thinking skills is due to STEM is an integrated learning approach that encourages learners to think more broadly about realworld problems based on learners' learning experiences. Components and foundations in STEM are problem solving through innovation, design, manipulating, collaborative learning environment, developing, utilizing technology, focusing on things that happen in life, and lies in learning to produce critical thinking skills and process-based that generate curiosity and able to find solutions to a problem (Sriani, 2015).

Learning in a STEM context will be a relevant education if the learning process has a positive impact on the lives of learners. The positive impact can be in the form of meeting needs according to learners' interests and in terms of anticipation of future needs that learners may not have realized. Teachers should provide opportunities to learners so that learners can develop creative ideas and develop their expertise in applying STEM mindsets and acting in relevant contexts (Daud 2012).

The skills and abilities trained through STEM include in-depth knowledge of problem-solving and are closely related to skills with a wide variety of jobs that are constantly evolving and becoming very important in the world of work in the future which based on the educational point of view of learners are required to have skills (Cahyani, 2012).

From a social point of view, STEM helps a person develop various skills and mindsets to enable learners to see and reach opportunities by being trained and developed. The ability to think and solve problems depends largely on how facts relate to each other based on concepts, basic big ideas, schematics, broad knowledge bases, and structure to easily understand new information (Bower et al., 2014). 


\section{Method}

This research was conducted on ecosystem material at Madrasah Tsnawiyah Negeri 4 Aceh Besar in class VII, even during the 2019/2020 academic year. The approach used in this study is a descriptive quantitative approach, namely the research conducted to determine the value of variables without making comparisons or connecting with other variables. All information is presented in numbers and analyzed based on the statistical analysis used to obtain descriptions and descriptions of the implementation of the learning model based on STEM (Sugiyono, 2016).

The population in this study is all students of class VII MTsN Aceh Besar, with a total of 120 learners. The parameters measured in this study are critical thinking skills. Instruments are used to measure problem-solving skills using reasoned multiple-choice questions (Fitriani et al., 20190). Test questions used to get data on critical thinking skills are a matter of multiple-choice reasoned numbering ten questions. The data collection technique that researchers use is a test. Written tests are conducted to determine learners' critical thinking skills after following the teaching and learning process on ecosystem materials and the creation of miniature ecosystems using STEM-based Experiential Learning learning.

The design of this study uses One Groups Pretest-Posttest Design, namely a research design that has a pretest before being given treatment and a posttest after being treated so that it can be known more accurately because it can be compared with being held before being treated using an experimental class not using a control class (Sugiyono, 2016).

The use of this design obtains data from the results of treatment on the subject of the study on the dependent variable, which is carried out in three ways, namely 1) the implementation of the pretest to measure the dependent variable, 2) the implementation of the treatment (independent variable) for the subject under study, and 3) the implementation of the posttest to measure the dependent variable after treatment. The experimental data was carried out by comparing the scores of the pretest and posttest results.

The following research design, One Group Pretest-Posttest Design, can be described in Table 1. as follows.

Table 1. One group pretest and posttest design

\begin{tabular}{llll}
\hline Group & Pretes & Treatment & Posttest \\
\hline Treatment & $\mathrm{Q}_{1}$ & $\mathrm{X}$ & $\mathrm{Q}_{2}$ \\
\hline & & &
\end{tabular}

Information:

$\mathrm{O}_{1}$ : Test before applying the STEM-based Experiential Learning model
X : Model application treatment STEM-based Experiential Learning

$\mathrm{O}_{2}$ : Tests after the application of the STEM-based Experiential Learning model

The percentage formula is used to find out the results of the implementation of the STEM-based Experiential Learning learning model on the critical thinking skills of students in class VII MTsN 4 Aceh Besar. To calculate the percentage by adding up and comparing it with the expected number so that mastery of critical thinking skills is obtained. The process of converting from scores to percentages is used in the following equation.

Persentase hasil $=\frac{\text { Shor jawaban siswa }}{\text { Skor total }} X 100 \% \ldots . .(1)$

The interpretation of the categorization of critical thinking skills uses a percentage assessment as presented in Table 1.

Table 1. Critical Thinking Percentage Assessment

\begin{tabular}{lll}
\hline No & Rating Level & $\begin{array}{l}\text { Critical Thinking } \\
\text { Criteria }\end{array}$ \\
\hline 1 & $80.10-100.00$ & Very high \\
2 & $60.10-80.00$ & Tall \\
3 & $40.10-60.00$ & Low \\
4 & $0.00-40.00$ & Very low \\
\hline
\end{tabular}

After obtaining a critical thinking skill score, then the one-sample t-test, which had previously been conducted Kolmogorov-Smirnov normality test with criteria $\mathrm{p}>0.05$, then distributed normally

\section{Result and Discussion}

Based on the research that has been done, the data obtained from the results of critical thinking skills on ecosystem materials implemented in the implementation of STEM-based Experiential Learning at MTsN 4 Aceh Besar with a description of the results presented as follows. The initial ability test of critical thinking skills is used to see the initial abilities of students before learning is carried out, and after learning is carried out using critical thinking instruments with reasoned multiple-choice questions. The ability test used the One Simple t-test, which was previously tested for normality with the Kolmogorov Smirnov test. The analysis of the average ability of the initial critical thinking skills (pretest) and the end (posttest) obtained the results of the pretest, which is 50.29 , while the posttest 79.41 can be seen in the table below. 
Table 2. Average pretest-posttest critical thinking skills

\begin{tabular}{lll}
\hline No & Treatment class & Average critical thinking \\
\hline 1 & Pretest & 50.29 \\
2 & Posttest & 79.41 \\
\hline
\end{tabular}

Table 2 above shows that the average pretest score is 50.29 indicating that the ability is still low. While the posttest was 79.41, which showed the high category, to see that both data were normal, the Kolmogorov-Smirnov normality test was carried out, which can be seen in Table 3 .

Tabel 3. Kolmogorov-Smirnov test critical thinking skills

\begin{tabular}{llll}
\hline No & Treatment class & $\begin{array}{l}\text { Average critical } \\
\text { thinking }\end{array}$ & Normality*) \\
\hline 1 & Pretest & 50.29 & Sig $0.112>0.05$ \\
2 & Posttest & 79.41 & \\
\hline
\end{tabular}

Information:

*)= Kolmogorov-Smirnov Test (Normal, Sig > a 0.05)

Table 3 above shows that the significance level of the Kolmogorov-Smirnov normality test is 0.112 , which shows that the data is normally distributed because the significance value is $0.112>0.05$. Furthermore, the OneSample t-Test was carried out, which can be seen in Table 4.

Table 4. Results of t-test of critical thinking skills

\begin{tabular}{llll}
\hline $\begin{array}{l}\text { Treatment } \\
\text { class }\end{array}$ & $\begin{array}{l}\text { Average } \\
\text { critical } \\
\text { thinking }\end{array}$ & Normality*) & Significance $\left.{ }^{* *}\right)$ \\
\hline Pretest & 50.29 & Sig $0.112>$ & 0.00 or \\
Posttest & 79.41 & 0.05 & $\begin{array}{l}\text { t-count }>\text { t-table, } 111.31 \\
\end{array}$ \\
& & & $\begin{array}{l}>1.66,170.57>1.66, \\
\text { really different }\end{array}$ \\
\hline
\end{tabular}

Information:

*)= Kolmogorov-Smirnov Test (Normal, Sig > a 0.05)

$* *)=$ One Sample $t$ Test (Normal, Sig < a 0.05)According to

Table 4, the significance level of the t-test is 0.00 , smaller than $0.05(0.00<0.05)$. The data is significant or really different between pretest and posttest, meaning that Ha is accepted and Ho is rejected, so it can be said that there is a significant increase in the critical thinking skills of learners using STEM-based Experiential Learning.

So, the results of the study indicate that the significant difference in increasing students' critical thinking skills with the application of STEM-based Experiential Learning is higher and has the idea that learning is effective and achieved.

In the application of the STEM-based Experiential Learning model, the learning process looks more passionate in learning. Based on experience through direct observation, students can see real examples of ecosystems happening in the environment. Direct experience makes them more interested and fosters curiosity about their learning material (Savicki, 2008; Mardhiyana \& Sejati, 2016).

In experiential learning, the teacher formulates what wants to be the final goal of the learning process (Aini \& Azizah, 2019) and starts the material by providing stimulation in the form of real events. By providing stimulation through experiential learning, learners can see reason, a thinking ability closely related to reaching conclusions that can be improved through direct, intensive, and repeated training (Darling-Hammond et al., 2020). By having a reflective way of thinking, students are expected to be able to provide simple explanations by building basic skills to make further explanations by concluding and having strategies and tactics in solving a problem so that learners become more skilled (Medina et al., 2017; Yamazaki, 2004).

\section{Conclusion}

Based on the study results, there is a significant difference in improving students' critical thinking skills in ecosystem materials with the implementation of STEM-based Experiential Learning learning. Deepening influences learners' learning outcomes that can produce critical thinking skills that are students' competence after following the learning process for a period of time. Learning is recommended to use experience-oriented learning models and strategies, as a basic ability in understanding science concepts then the experience can affect critical thinking skills, but also influenced by other factors such as reason so that it can be said that experience and reasoning have a positive effect that results in improvements in critical thinking skills and provide cognitive development for learners.

\section{Acknowledgments}

The author would like to thank the supervisors and friends who have helped in the research and completing this paper

\section{References}

Aini, S., \& Azizah, S. (2019). English Teacher's Strategy in English Teaching Learning at the Fourth Grade of SD Negeri Kowel 3 Pamekasan in 2013 Curriculum. PANYONARA: Journal of English Education, 1(1), 17. https://doi.org/10.19105/panyonara.v1i1.2515

Aladé, F., Lauricella, A. R., Beaudoin-Ryan, L., \& Wartella, E. (2016). Measuring with Murray: 
Touchscreen technology and preschoolers' STEM learning. Computers in Human Behavior, 62, 433441.

https://doi.org/https://doi.org/10.1016/j.chb.2 016.03 .080

Bower, G.G. (2014). Theory and practice: Utilizing Dewey's experiential learning theory to implement a 5k road race. Journal of Hospitality, Leisure, Sport \& Tourism Education. Volume 15, 61-67. doi: https://doi.org/10.1016/j.jhlste.2014.06.001

Bybee, R.W. (2013). The Case for STEM Education: Challenges and Opportunity. Arlina, Virginia: NSTA Press.

Cahyani, I. (2012). Pembelajaran menulis berbasis karakter dengan pendekatan experiential learning. Bandung: Program Studi Pendidikan Dasar SPS UPI [Indonesian]

Cahyo, A N. (2013). Panduan Aplikasi Teori-Teori Belajar Mengajar Teraktual dan Terpopuler, Yogyakarta: DIVA Press. [Indonesian]

Darling-Hammond, L., Flook, L., Cook-Harvey, C., Barron, B., \& Osher, D. (2020). Implications for educational practice of the science of learning and development. Applied Developmental Science, 24(2),

97-140. https:// doi.org/10.1080/10888691.2018.1537791

Daud, F. (2012). Pengaruh Kecerdasan Emosional (EQ) dan Motivasi Belajar terhadap Hasil Belajar Biologi Siswa SMA 3 Negeri Kota Palopo. Jurnal Pendidikan Dan Pembelajaran (JPP), 19(2), 243-255. http://doi.org/10.1287/moor.2013.0633. [Indonesian]

Ennis, R. H. (2011). The nature of critical thinking: An outline of sritical thinking dispositions. University of IIIinois. Retrieved from: https://www.yumpu.com/en/d...-our-faculty

Fathurrohman, M. (2015). Model-Model Pembelajaran Inovatif. yogyakarta : Ar-Ruzz Media. [Indonesian]

Fitriani, A., Zubaidah, S., Susilo, H., \& Muhdhar, M. (2019). The Integrated Problem Based Learning and Predict, Observe, Explain (PBL-POE) to Empower Students' Problem-Solving Skills. In ICEMT 2019: Proceedings of the 2019 3rd International Conference on Education and Multimedia Technology. https://doi.org/10.1145/3345120.3345139

Khoiriyah, N., Abdurrahman, A., \& Wahyudi, I. (2018). Implementasi pendekatan pembelajaran STEM untuk meningkatkan kemampuan berpikir kritis siswa SMA pada materi gelombang bunyi. Jurnal Riset Dan Kajian Pendidikan Fisika, 5(2), 53-62. doi:http://dx.doi.org/10.12928/jrkpf.v5i2.9977. [Indonesian]
Kusuma, Y.A. (2014). Penerapan Model Experiental Learning Pada Materi Luas dan Keliling Persegi Panjang Di Kelas VII-1 SMP Negeri 22 Surabaya. Jurnal MathEdunesa. 3(3). doi: https://doi.org/10.26740/mathedunesa.v3n3.p $\% 25 p$ [Indonesian]

Marjan, J., Arnyana, I.B.P., \& Setiawan, I.G.N. (2014). Pengaruh Pembelajaran Pendekatan Saintifik Terhadap Hasil Belajar Biologi dan Keterampilan Proses Sains Siswa MA Mu ' allimat NW Pancor Selong Kabupaten Lombok Timur Nusa Tenggara Barat. Jurnal Pendidikan IPA, 4(1), 1-12. http://doi.org/10.1089/omi.2012.0013. [Indonesian]

Medina, M. S., Castleberry, A. N., \& Persky, A. M. (2017). Strategies for Improving Learner Metacognition in Health Professional Education. American Journal of Pharmaceutical Education, 81(4), 78. https://doi.org/10.5688/ajpe81478

Savicki, V. (2008). Experiential and Affective Education for International Educators: Developing Intercultural Competence and Transformation. Sterling: Stylus Publishing

Sriani, N.K., Sutama, I.M., \& Darmayanti, I.A.M. (2015). Penerapan model pembelajaran experiential learning untuk meningkatkan kemampuan menulis paragraf deskripsi pada siswa kelas VII B SMP Negeri 2 Tampaksiring. Jurnal Pendidikan Bahasa dan sastra Indonesia, 3(1). doi: http://dx.doi.org/10.23887/jipbs.v3i1.4776 [Indonesian]

Sugiyono. (2016). Metode Penelitian Kuantiatif, Kualiatatif, dan R\&d. Bandung Alfabeta, CV. [Indonesian]

Syarif, S., \& Darwansyah. (2010). Strategi Belajar Mengajar. Jakarta: Ar-ruz Media. [Indonesian]

Yamazaki, Y., \& Kayes, D. C. (2004). An Experiential Approach to Cross-Cultural Learning: A Review and Integration of Competencies for Successful Expatriate Adaptation. Academy of Management Learning and Education, The, 3, 362-379. https://doi.org/10.5465/AMLE.2004.15112543

Yardley, S., Teunissen, P. W., \& Dornan, T. (2012). Experiential learning: transforming theory into practice. Medical teacher, 34(2), 161-164. https://doi.org/10.3109/0142159X.2012.643264. 